\title{
Demographic and Economic Dependency Ratios - Present and Perspectives
}

\author{
Mihail Titu ${ }^{1}$, Ilie Banu ${ }^{1} \&$ Ioana-Madalina Banu ${ }^{1}$ \\ 1 "Lucian Blaga" University of Sibiu, Sibiu, Romania \\ Correspondence: Ilie Banu, "Lucian Blaga" University of Sibiu, B-dul Victoriei nr. 10, Romania. Tel: \\ 40-74-047-0069. E-mail: ilie.banu@ulbsibiu.ro, iliebanu@yahoo.com
}

$\begin{array}{lcc}\text { Received: July 24, } 2012 & \text { Accepted: October 12, } 2012 \quad \text { Online Published: October 23, } 2012 \\ \text { doi:10.5539/ijef.v4n12p214 } & \text { URL: http://dx.doi.org/10.5539/ijef.v4n12p214 }\end{array}$

\begin{abstract}
In the present research article, we outline the distinction between the demographic dependency ratio and the economic dependency ratio and present its evolution in Romania within the European Union, but not restrictive to the EU27.

The evolution of demographic dependency ratio changed dramatically in Romania in the last 15 years comparing to the UE27. On the other hand, the evolution of economic dependency ratios is much more relevant because it also reflects the problems the economy is facing and should be brought to the fore in the political debates and to decision makers.

In the paper we present the factors that are leading to the increase of the economic dependency ratio and we conclude with the solutions which a state has to adopt in order to prevent excessive public debt and structural gaps due to long term rise in economic dependency ratio. Moreover, policy-makers must face up the painful inter-temporal transfer choices that have to be done. Our concern about Eastern-European Countries is strengthened by the global results reached by OECD through Minilink Model Study, IMF Study of G7 and QUEST II Model that suggest the fall of the living standards over the next 50 years due to economic dependency ratio. For Romania we considered two main solutions to this problem: increasing birth rate (long term solution) and lowering the unemployment rate through investment and a high rate of EU funds absorption (medium term solution).
\end{abstract}

Keywords: demographic dependency ratios, economic dependency ratios, public debt, structural gap, living standards, Romania, European Union

\section{Introduction}

\subsection{Introduce the Problem}

In the current context of economic crisis and the prospect of having a crisis in "W" in Romania, due to the spread of the waves of crisis in other European countries and America, but also due to the lack of a set of policies focused on sustainable development of public finance we want to perform a comparative analysis outlook on sustainability in case the economic dependency ratio will increase knowing that the ageing of the population is one of the main challenges across Europe. Dependency ratio is defined as a measure of the portion of a population which is composed of dependents (people who are too young or too old to work). The dependency ratio is equal to the number of individuals aged below 15 or above 64 divided by the number of individuals aged 15 to 64 , expressed as a percentage. A rising dependency ratio is a concern in many countries which are facing an aging population, since it becomes difficult for pension and social security systems to provide for a significantly older, non-working population. (www.investorwords.com/1409/dependency_ratio)

We present here Roubini's opinion that the second high recession will began in 2013-2014, due to the fact that all the countries which face difficulties try to delay their debts as long as possible. But we see that this method will not be a long-term one because of the lack of confidence of the investors, as we can see nowadays if we look at the results of the stock-market. (Roubini, 2012)

\subsection{Explore Importance of the Problem}

The OECD estimates that by 2050 there could be on average more than 70 older and inactive people for every 
100 workers in OECD countries (the figure is currently at 38 in OECD countries). In Europe, this number may even approach 100. This fact would place enormous pressure on the public finances of countries. In addition, declining workforces and labor participation cause a reduction in labor supply in many European countries, putting upward pressure on wages. In 2007, the EU workforce numbered 194 million workers. By 2050, there will be an estimated labor shortage of 32 million workers. In Germany and Italy with workforces of 35 and 22 million, respectively, the labor shortage is estimated to reach 8 and 6 million, by 2050. In France and the UK the problems are less critical with estimated shortages of 1 and 0.5 million workers. Considering the emigration of white collars from East-Europe, including Romania, to better paid jobs in developed countries, the East-European countries will face serious problems regarding this fact unless they will find a solution.

It is inevitable that existing tax systems will be revised in response. Favorable tax arrangements for early retirement and special tax arrangements for those already retired must be re-examined. It is also critical to bring more people into the workforce by removing disincentives that make it attractive for the unemployed to remain unemployed. Given current forecasts on economic growth, government spending and tax revenues, today's policies in most OECD countries are not sustainable and need to be changed. (Vermeend, 2008)

The conclusions of an OECD study outline the following: (Türk, 2011)

- The ageing of the populations is one of the main challenges across Europe

- A clear distinction has to be made between (Method of calculation the indicators):

- $\quad$ DEMOGRAPHIC DEPENDENCY RATIOS - (Old Age) (people aged 65+ relative to people aged 15-64) and Young Age (people aged $<15$ relative to people aged 15-64)

- ECONOMIC DEPENDENCY RATIOS (inactive persons relative to people in employment)

- The evolution of economic dependency ratios is much more relevant and should be brought to the fore in the political debate

\subsection{State Hypotheses and Their Correspondence to Research Design}

The purpose of this article is to identify factors leading to increase in economic dependence and to offer possible alternatives and solutions to avoid a galloping increase of dependence rate, which of course is not desirable, but to some extent is difficult to avoid.

Economic dependency ratio, not retirement age, will determine future pension funding needs. "By far the most effective response to an ageing population in Europe is to make full use of available employment potential", noted Leila Kurki, president of the Section for Employment, Social Affairs and Citizenship of the European Economic and Social Committee.

If the aim was to rise the retirement age, it was necessary to ensure that people were able and willing to work for longer. "Jobs must be designed so that people are able to work at least up to the statutory retirement age." Kurki pointed out that this would entail radical changes in the working life.

Work and management would have to be organized in a way that will accommodate ageing at every stage of a person's career. Working conditions and the working environment must be adapted to suit workers of different ages. Discrimination and negative value judgments against older workers must be combated. Updating professional skills and preventive healthcare are of key importance. (European Economic and Social Committee, 2011)

\section{Current Status and Perspectives of the Ratios}

Due to the the high novelty of the paper and the macroeconomic approach, we had to use statistics and Eurostat databases, so the first assumption is that the errors due to collecting the data are limited. We present the current status of research, which is somehow limited in the field and continued with our assumptions based on forecasted figures presented by authorities. Most of the countries are affected by changes in the structure of the population so the calculation methods of the two rates have to be well understood and analyzed.

\subsection{Demographic Dependency Ratios}

The population pyramid is a demographic instrument showing the age structure of the population in a country at a particular time. It is composed of two side by side graphs containing the number of men and women according to age.

Ideal pyramid - the basis of the pyramid reflects a high fertility to a level that ensures the smooth replacement of the population (2.1 children for women). A well balanced middle area shows the existence of sufficient adults who contribute to the social security and pension system. 
We have presented in Figure 1 a forecast of Romania's population till 2050 and how it should look as an ideal pyramid. (http://populatiaromanieiincotro.unfpa.ro/demografic)
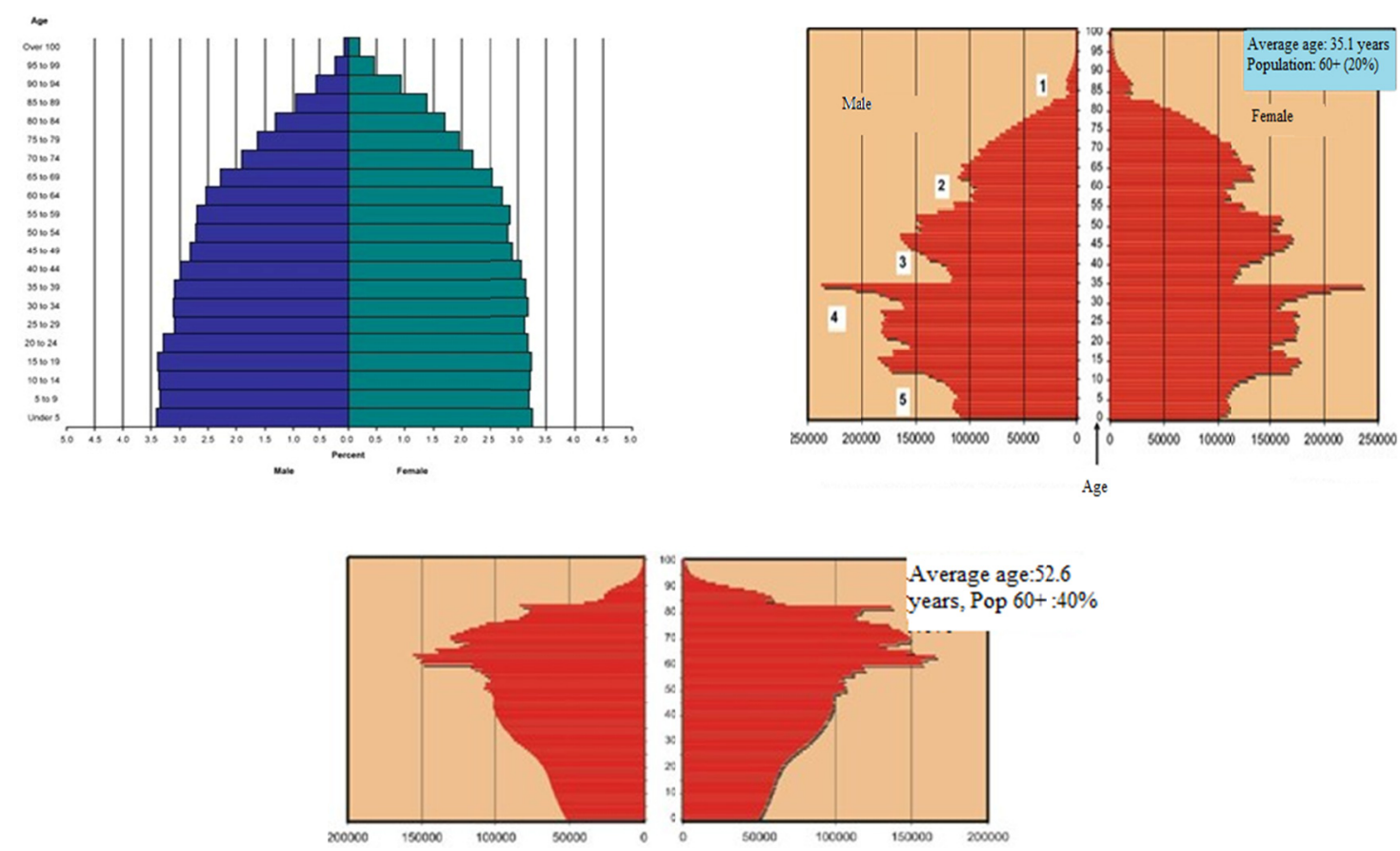

Figure 1. The ideal pyramid vs. Romania's population nowadays vs. Romania's population in 2050

The left graphic from Figure 1 represents the ideal pyramid and on the right side we have shown Romania's population nowadays and the graph below represents the forecast for Romania's population in 2050. Speaking about the right graph, the first period corresponds to the First World War, a period with an important birth decrease. The second period represented in the right figure above represents the Second World War, where there was another birth decrease. The third birth decrease was during the 1956-1966 due to free access to contraceptive methods and pregnancy abortion. The forth period, between 1967 and 1989, when contraceptive methods and pregnancy abortion were forbidden, led to a "baby boom". In the last period, as a consequence of the revolution of 1989 population had again free access to contraceptive methods and pregnancy abortion and as a result the number of births decreased a lot.

But thinking of the period when the "baby boom" generation (1946-1956) will retire (2011-2020) the pressure on the social contributions budget will increase. The increase will put an additional pressure on public debt and budget deficit of many countries, especially on those that had already a structural problem. This problem can lead to the second wave of cries, facing structural problems regarding social security funds and health and problems of financing the deficits and public debt.

\subsection{The Evolution of Romania's Population}

In 2006, the population of Romania was estimated at 21.6 million, had a large mass of adults (10.5 million), and retired people ( 6 million) and few children ( 5 million people under 18). Narrow base shows that fewer children are born (about 220,000, to 350,000, which would ensure population replacement).

In 2011, the population decreased to 19.04 million people and was the highest decrease from the UE27. (www.econtext.ro, 2012)

The pyramid also includes more than 3 million Romanian legally residing abroad and those who are abroad illegally and whose number is unknown. According to EUROSTAT statistics Romania has another problem. For example, it is stated that in 2009 Romania had only 0.1 foreign citizens compared to the EU27 average of 6.5. That means that only few people are coming and settling in Romania whereas more than $10 \%$ are leaving for other countries where they find better conditions. (Active ageing and solidarity between generations, 2012)

After the referendum organized at the end of 2011, the National Institute of Statistics offered the following result: 
stabile population - 19.042.936 .

Even considering the decreasing population in Romania, the total age dependency ratio (43\%) is placed below compared to the average (49.3\%) in EU27. The value of our country is close to countries like Poland, the Czech Republic, Cyprus, Malta and Slovenia.

Table 1. Dependency ratio within the EU27 in 2010 (ascendant ordered)

\begin{tabular}{|c|c|c|c|c|c|}
\hline & $\begin{array}{l}\text { Median } \\
\text { age(years) }\end{array}$ & $\begin{array}{l}\text { Young age } \\
\text { dependency } \\
\text { ratio (\%) } \\
\end{array}$ & $\begin{array}{l}\text { Old age } \\
\text { dependency } \\
\text { ratio(\%) }\end{array}$ & $\begin{array}{l}\text { Total age } \\
\text { dependency } \\
\text { ratio(\%) }\end{array}$ & $\begin{array}{l}\text { Share of } \\
\text { population aged } \\
80 \text { or over }(\%)\end{array}$ \\
\hline Slovakia & 36.9 & 21.2 & 16.9 & 38.1 & 2.7 \\
\hline Poland & 37.7 & 21.2 & 19.0 & 40.2 & 3.3 \\
\hline Czech Republic & 39.4 & 20.2 & 21.6 & 41.7 & 3.6 \\
\hline Cyprus & 36.2 & 24.1 & 18.6 & 42.7 & 2.9 \\
\hline Romania & 38.3 & 21.7 & 21.4 & 43.0 & 3.1 \\
\hline Malta & 39.2 & 22.4 & 21.2 & 43.6 & 3.3 \\
\hline Slovenia & 41.4 & 20.2 & 23.8 & 44.0 & 3.9 \\
\hline Lithuania & 39.2 & 21.8 & 23.3 & 45.0 & 3.6 \\
\hline Bulgaria & 41.4 & 19.7 & 25.4 & 45.1 & 3.8 \\
\hline Latvia & 40.0 & 20.0 & 25.2 & 45.1 & 3.9 \\
\hline Hungary & 39.8 & 21.5 & 24.2 & 45.7 & 3.9 \\
\hline Luxembourg & 38.9 & 26.0 & 20.4 & 46.4 & 3.6 \\
\hline Spain & 39.9 & 21.9 & 24.7 & 46.6 & 4.9 \\
\hline Estonia & 39.5 & 22.3 & 25.2 & 47.5 & 4.1 \\
\hline Austria & 41.7 & 22.0 & 26.1 & 48.1 & 4.8 \\
\hline Ireland & 34.3 & 31.7 & 16.8 & 48.5 & 2.8 \\
\hline Netherlands & 40.6 & 26.2 & 22.8 & 49.0 & 3.9 \\
\hline EU-27 & 40.9 & 23.3 & 25.9 & 49.3 & 4.7 \\
\hline Portugal & 40.7 & 22.7 & 26.7 & 49.4 & 4.5 \\
\hline Greece & 41.7 & 21.5 & 28.4 & 49.9 & 4.6 \\
\hline Finland & 42.0 & 25.0 & 25.6 & 50.6 & 4.6 \\
\hline United Kingdom & 39.6 & 26.4 & 24.9 & 51.3 & 4.6 \\
\hline Belgium & 40.9 & 25.6 & 26.0 & 51.7 & 4.9 \\
\hline Germany & 44.2 & 20.5 & 31.4 & 51.8 & 5.1 \\
\hline Italy & 43.1 & 21.4 & 30.8 & 52.2 & 5.8 \\
\hline Denmark & 40.5 & 27.6 & 24.9 & 52.4 & 4.1 \\
\hline Sweden & 40.7 & 25.4 & 27.7 & 53.1 & 5.3 \\
\hline France & 39.8 & 28.6 & 25.6 & 54.2 & 5.2 \\
\hline
\end{tabular}

Source: (Eurostat, europop 2012)

In order to study the correlation coefficient, according to Pearson, SAS program uses the following formula (Dootz, 2000)

$$
\text { CORREL }(X, Y)=\frac{\sum x x^{*} y i-n^{*} x^{*} y}{\sqrt{\left(\sum x_{i}^{2}-n * \bar{x}^{2}\right) * \sum y_{i}^{2}-n * \bar{y}^{2}}}
$$

The correlation coefficient can take any value between [-1.1]. When the values are closer to 1, it means a strong relation. Regarding the influence young age dependency ratio and old-age dependency ratio is having on the total age dependency ratio at the European level in 2010, we calculated the correlation coefficient. We have structured the results in the table 2 : 
Table 2. Relation between the two variables

\begin{tabular}{ccc}
\hline $\begin{array}{c}\text { Total age dependency } \\
\text { ratio(\%) }\end{array}$ & CORREL & COVAR \\
$\begin{array}{c}\text { Young age dependency } \\
\text { ratio(\%) }\end{array}$ & 0.522597 & 6.2054537 \\
$\begin{array}{c}\text { Old age dependency } \\
\text { ratio(\%) }\end{array}$ & 0.7185678 & 10.46018 \\
\hline
\end{tabular}

Source: Author's compilation using SAS

Based on the data we can conclude that old age dependency ratio has a bigger influence on total age dependency ratio.

In a study presented by Eurostat it is shown that Romania's population will fall sharply in the next 50 years to 17 million in 2060 and this means that healthcare and pension expenditure will rise rapidly.

Romania is part of the group of countries where the dependency ratio will increase rather alarmingly, exceeding $60 \%$ by 2060 , together with Bulgaria, Germany, Latvia, Poland and Slovakia. Romania's population could fall by $7.5 \%$ by 2035 compared to 2010, the fourth decline in the EU, after those recorded by Bulgaria, Latvia and Lithuania, while the EU population would increase by 2035 , nearly $5 \%$, but then followed by a downward spiral, according to the release of INS.

Which are the consequences of this decline? First, the report of the inactive and employed population will decrease meaning that economic dependency will increase. At the same time it should be correlated with lower birth rates and growing life expectancy.

Secondly, we have to mention that Romanians tend to migrate and work under better conditions and for better wages abroad.

But how can we ensure a sustainable growth? Romanians' living standards should converge to that of other Europeans. How can we bring more money into the economy? First, producing more, increasing the number of employees, especially those productive. Mr. Franks warned that there are a lot of Romanians working abroad, who have very good results and who could be attracted to work in the country. We agree with this view, but also wonder why some policies are not made to target this and when are we going to start seeing results.

Romania by 2050 - the most pessimistic version of demographers indicates a dramatic decline and aging of population. Considering that fertility has remained at the same level, while the number of elderly continues to grow with increasing life expectancy, Romania's population will reach 16 million. The number of active adults will be so small that the dependency ratio (age adults to support vulnerable groups: children and elderly) will be increasing a lot. (Note 1)

"Member States' labor market survey statistics and results in early 2010 show that almost 2.5 million Romanian and Bulgarian people worked in EU15 countries. Out of these, 2.1 million people are Romanian, the majority working in Italy $(890,000)$, Spain $(825,000)$ and Germany $(110,000)$ ", said Cristina Arigho, spokesperson for the department of Employment, Social Affairs and the inclusion of the European Commission.

Official statistics outline that the remaining 275,000 Romanians are working in Austria, Belgium, Denmark, Finland, France, Greece, Ireland, Luxembourg, Netherlands, Portugal, Sweden and the UK. Ten of these countries (Belgium, Germany, Ireland, France, Italy, Luxembourg, Malta, Netherlands, Austria and Britain) have maintained some restrictions on Romania before its accession to the EU, among which the need of obtaining a work permit for certain qualifications.

A percentage of the total population of immigrants varies from $0.1 \%$ in Poland to $7 \%$ in Italy and Britain and even reaches $43 \%$ in Luxembourg.

Romania with 2.8 million immigrants recorded in the World Bank's report in 2010 has a share of immigrants out of the total population of about $12.72 \%$ and the share of total population of Romania's population is $0.29 \%$. While Romanian immigrants in the total share of immigrants in the world is $1.3 \%$, that means that the average Romanian immigrants is four times higher than the world average. It is important to note the fact that about $12 \%$ of the total numbers of immigrants are people with higher qualifications and experience.

Taking into consideration the forecasted dependency ratio for Romania, we are going to present in Figure 2 the forecasts for EU27. 


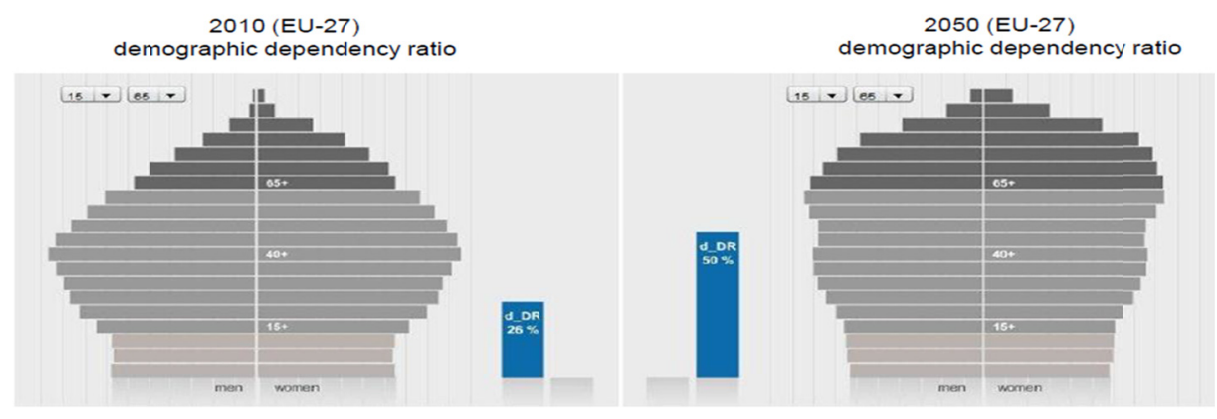

d_DR $=$ demographic dependency ratio: population $65+$ relative to $15-64$

Figure 2. Comparative demographic dependency ratio in EU27

(Source: AK-Wien / Dependency Ratio Calculator)

As we can see from the graphic presented in Figure 2, the demographic dependency ratio is forecasted to almost double in EU27 by 2050, but will not grow so much in comparison with the forecasted ratios for Romania. We have to question whether the forecast for Romania is well approximated or not and if the pessimistic version is not too pessimist? Next we present a study which aims at evaluating the burden of the dependency ratio increase and at answering the following question: "as the population grows older and the young people are replaced by the elderly, how is this going to affect the fiscal pressure for the employed persons with this demographic change? The results of the study show that even when the capacity of the employed population with supporting the fiscal pressure generated by the dependent population is not taken into consideration, the concerns regarding the increase of the fiscal pressure under the conditions of the dependency ratio increase are exaggerated, yet the budgetary expenditures owed to this implication are rising. (Ruggeri Joe, 2010)

But the conclusions are that there is actually a pressure on deficit grows, but even more there is the social problem that if there are fewer and fewer children, there will be fewer active persons that can support the expenditures of the $65+$ population. On the figure 3 , we presented the age structure in the left graph and the economic status of the people employment rate on the right.

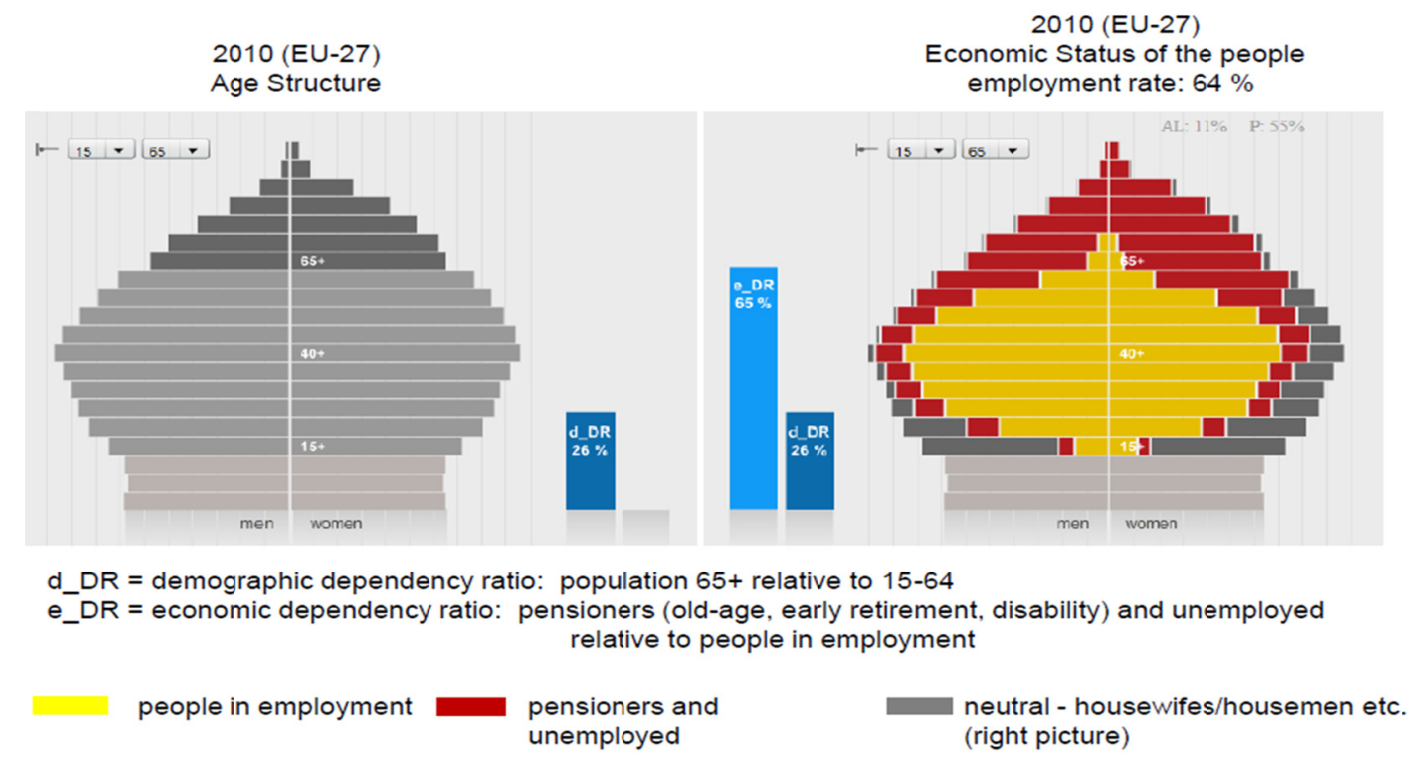

Figure 3. Demographic vs. Economic Dependency Ratio 2010 (EU-27)

\subsection{Economic Dependency Ratios}

In order to have a general overview, we have first presented the evolution of the economic dependency rate in 
EU 15, the US and Japan.

Table 3. Evolution of economic dependency rate from 1960-2050

\begin{tabular}{ccccccccc}
\hline \multicolumn{3}{c}{} & \multicolumn{3}{c}{$\begin{array}{c}\text { Potential economic dependency } \\
(0-14+65 s+) / \text { Active population }\end{array}$} & & & \multicolumn{2}{c}{$\begin{array}{c}\text { Effective economic dependency } \\
\left(0-14+65 s^{+}\right) / \text {Active employment }\end{array}$} \\
\hline & 1960 & 1995 & 2000 & $2050(\mathrm{f})$ & 1960 & 1995 & 2000 & $2050(\mathrm{f})$ \\
EU15 & 0.85 & 0.75 & 0.75 & 1.09 & 0.88 & 0.85 & 0.85 & 1.24 \\
US & 1.04 & 0.69 & 0.66 & 0.86 & 1.11 & 0.75 & 0.72 & 0.93 \\
Japan & 0.75 & 0.57 & 0.61 & 1.13 & 0.77 & 0.59 & 0.63 & 1.16 \\
\hline
\end{tabular}

Source: UN and Eurostat databases

Analyzing table 3 we can observe higher figures for effective economic dependency and that is because the active population will always be higher than active employment, the difference being the unemployed persons. In our opinion, it is better to look at effective economic dependency ratio when formulating conclusions. As we can observe in EU15 the ratio has increased by almost 41\% from 1960 to 2050. In Japan we have also an increase by $50,6 \%$ regarding the same period but in the US we can observe a decrease by $17 \%$ in the analyzed period.

\subsection{Figures for Romania}

We considered statistical figures from the International Labor Office and Romanian Institute of Statistics and we take figures for granted even though errors can occur.

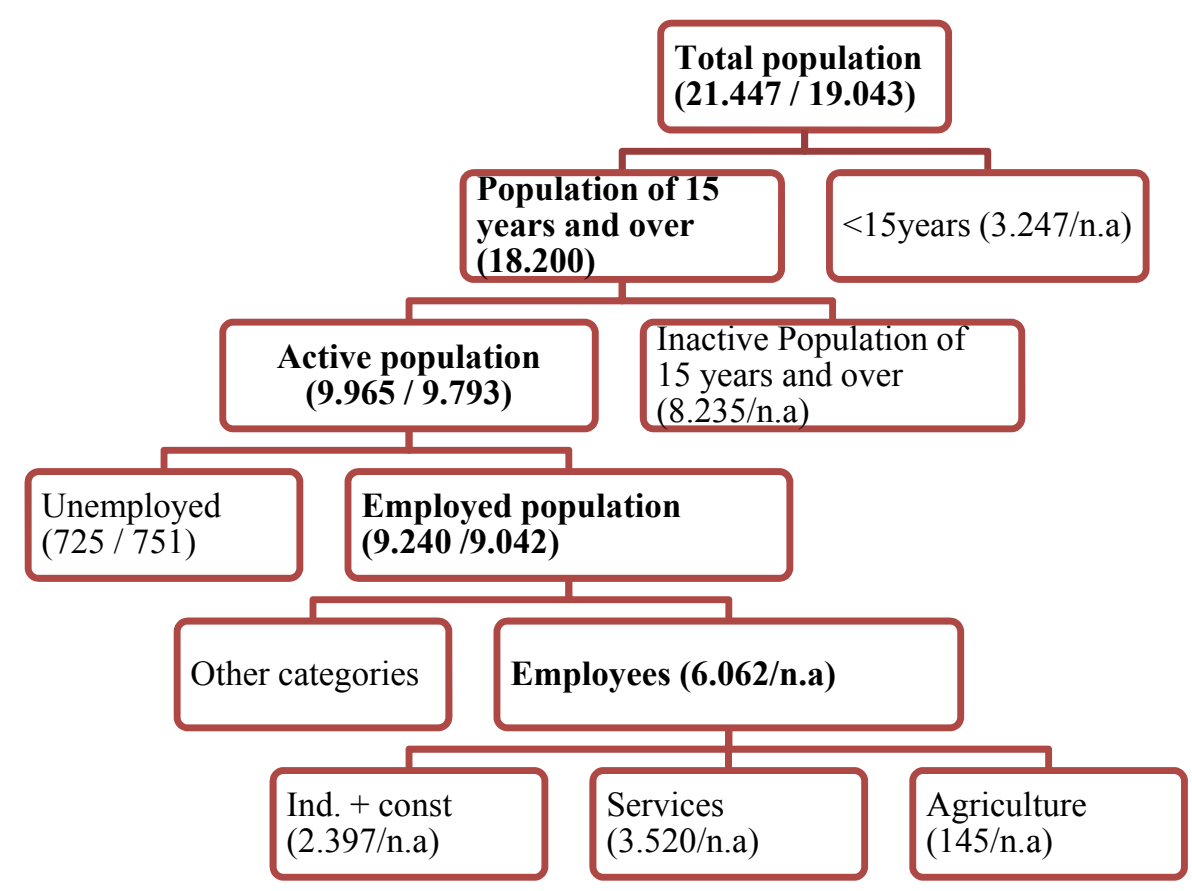

Figure 4. Population categories in 2010 vs. 2012

Source: International Labor Office

The economic dependency report (the number of inactive and unemployed persons which relate to 1000 employed persons) has been of $1321 \%$ in 2010 , higher for the female gender (1666\%, as opposed to $1043 \%$ o concerning the men) and for the urban environment (1340\%, compared to $1299 \%$ in the rural environment).

In the IVth quarter of 2011, the economic dependency report (the number of inactive and unemployed persons which relate to 1000 employed persons) has been of $1362 \%$. Practically, for each employed person in Romania, we have 1.362 inactive and unemployed persons.

The employment rate of the population aged 15-64 in the forth quarter of 2011 has been of $57.9 \%$, at a distance of 12.1 percentage points from the national target of $70 \%$ established in the context of the European Strategy 
2020 while the unemployment rate has reached the $7.7 \%$ level.

The employment rate of the population able to work (15-64 years) has been of $57.9 \%$. The occupancy has been higher amongst men $(64.8 \%$ as opposed to $51.1 \%$ for women); at the same time, the unemployment rate has reached the $8.2 \%$ level for men, as opposed to $7.0 \%$ for women.

The employment rate of youths (15-24 years) has been of $23.1 \%$ and the unemployment rate of $25.4 \%$. In other words, one out of four youths would want to work but cannot find a job. (Paul, 2012)

In conclusion, we find it obvious that the trend of economic dependency ratio is an ascendant one, not only in Romania or European Union, but also across the globe, as we have seen (US and Japan).

\section{Factors Leading to Increase in Economic Dependency Ratio}

Considering the formula:

$$
\text { Economic dependency rate }=(\text { Total inactive population }+ \text { Unemployed }) / \text { Employed people, }
$$

We can easily find the factors which affect the value of the economic dependency rate which considering the growing trend of the dependency rate are:

- The decline of the total population, especially of that under 15 years, more than the increase of $65+$ will lead to the increase of the total inactive population

- If unemployment rate is stable or growing the economic dependency rate will grow

The sole variant in which the growing trend can be slowed down is to lower the unemployment rate whereas employment rate increases, so as to lower the increase of inactive population, especially the old age dependency ratio.

We have to mention that lately there have been carried out several studies which outlined somehow the same solution which is that fiscal policy have to change. We will mention some studies such as:

- OECD, MINILINK Model Study of global consequences of ageing

- IMF STUDY OF G7 countries using the Multimodel MODEL

\section{- QUEST II Model}

Simulations with the QUEST II model, which take explicit account of the labor force and public finance implications of ageing, suggest per capita living standards are likely to fall significantly over the next 50 years due to the direct influence of the ageing process in the EU, US and Japan.

The effect of ageing populations in terms of slowing the rate of growth of potential output will also make the budgetary implications of ageing more difficult for the individual economies to bear.

Regarding the consequences of increasing economic dependency rate we mention:

- First and foremost, policy-makers will need to increasingly address the consequences of ageing for future living standards and face up to the painful inter-temporal transfer choices to be made in this regard i.e. how much should the present generation transfer in terms of physical and human capital in order to ensure that the retirement of the "baby boom" generation doesn't pose insurmountable problems. Recently, tax reforms left less revenue for boomers benefits, but still boomers are an important share of population which vote almost entirely, so political parties tend to overprotect the generation. It is the case of Romania, too and the government should take care on budget deficit and public debt.

- Secondly, fiscal policy will need to be closely scrutinized in order to be able to cater for the inevitable age related spending pressures which will emerge, without provoking the development of unsustainable deficit and debt positions and significant disincentive effects in relation to work effort and labor supply decisions. (Mcmorrow \& Roeger, 2010)

The results of a study conducted by the International Monetary Fund in 2011 revealed that in US those aged 65 may receive $\$ 300$ billion more in benefits than they pay in taxes, which represents an obligation 17 times larger than that likely to be left by those aged 25

- Last but not least unemployment rate has strong relationships with important economic variables like budget deficit and public debt, economic growth, etc. Carmen Reinhart and Kenneth Rogoff, two Harvard economists, estimate that public debt above $90 \%$ of GDP can reduce average growth rates by more than $1 \%$. . (Economist, 2012)

Regarding the last statement, the standard level of the unemployment rate in an economy is $5-6 \%$. At a given 
unemployment rate the budget deficit can be estimated. To this level the size of revenue and expenditure can be estimated corresponding to an employment rate of $94-95 \%$ from the active population. For the U.S. economy it was estimated, for example, that each percentage point of increase in the unemployment rate increases the budget deficit to $\$ 30$ billion. This growth deficit is due to the fluctuations in the economic activity and the deficit is caused by the highest possible occupancy rate of the population, within a given budget year. After its removal, the remaining deficit reflects structural imbalance between revenues and government expenditures. A deficit caused by unemployment of more than $4 \%$ of GDP was recorded during the war and in times of economic downturn. (Hyman, 2007) We have to outline also the tax force to retire, speaking about social contributions that encourage people to retire rather than continue working and the unused labor force capacity which should lower the economic dependency rate. The policy makers should consider these aspects too. (Wise, 2005)

In our opinion government agencies should develop long term budget projections but in some east European countries there are not even medium term budget projections. This is extremely important, considering the aging population and the increase in economic and demographic dependency ratios. Behavioral evidence suggests that people tend not always to make decisions in far-sighted and rational ways. Individuals with inadequate retirement savings are also more likely to draw on costly state benefit programmers in retirement. Encouraging them to save in a pension when young makes this less likely. Today, policy changes should be undertaken in light of this sobering long-term outlook, but also with a full appreciation of the degree of uncertainty about these pressures. We strongly believe that long term projections should be made throw statistical model simulations. (Lee, 2005)

We want to highlight that, even though there are agencies that are doing research in the field of aging (for example, The National Institute on Aging in US, Aging Report conducted by EUROSTAT), when designing budgets governments do not take into consideration all the limits that might occur such as the effect on budgets of the aging population. (Suzman, 2005)

\section{Conclusions and Discussion}

When optimal taxation is considered, the governments should consider the effects of a fiscal policy aiming at redistributing the tax burden in such a way to maintain per-capita debt unchanged. The latter tax reform implies that capital intensity and the population growth rate move in the same direction as the change in the tax on population size, while consumption can move in either direction in the presence of convex childbearing costs. A solution can be increasing the tax on the family size and reducing the taxes on capital income. (Spataro L., 2012) The economic consequences of rising economic dependency ratio are severe and we have mentioned above just some of them. Although to some extent economic dependency ratio cannot be avoided, a common strategy has to be adopted at the EU level in order to maintain the ratio at a sustainable level. Although population dependency ratio can on long term be supported by stimulating birth grow, speaking about economic dependency ratio the state has to stimulate job creation in order to reduce unemployment.

Austerity cannot be taken as a sole solution because the consolidation needed would be too large.

Another solution to shrink the public debt can be inflation but the boomers or those who have large savings and that are often in a decision making position will not agree upon this solution. We consider that inflation cannot solve the real problems of structural imbalances.

A real opportunity for lowering the unemployment rate is investing and a high rate of EU funds absorption. Especially, for East European Countries the allocation is substantial but in some cases this opportunity is not valued. This is the case of Romania, which has a rate of EU funds absorption of less than $10 \%$ and at the moment has its funds partially blocked by the European Commission for irregularities detected by the auditors. Considering the scenario that Romania would have absorbed 10 billion euro, the demand wouldn't have decreased whereas the economy stimulated, the value added tax and the salaries in the public sector could have remained the same. (Anghel, 2012)

In almost all reports that present the two ratios, especially the economic dependency ratio it is argued that the most effective strategy with which countries can prepare for population ageing is raising employment levels. (Demography Report, 2008)

Regarding the conclusions, this study can be continued with an analysis of labor force implications of a rise in dependency ratios. 


\section{Acknowledgements}

Research conducted within the POSDRU/CPP107/DMI1.5/S/76851 project, co-financed from the European Social Fund through the Human Resources Development Sectorial Operational Program 2007-2013.

\section{References}

Anghel,

A. $\quad$ M.

$(2012$,

October

26).

http://www.zf.ro/analiza/daca-zf-a-imaginat-un-exercitiu-in-care-in-loc-de-1-8-mld-euro-am-fi-luat-10-mldeuro-bani-europeni-10257897. Retrieved 10 2012, 2012, from www.zf.ro: http://www.zf.ro/analiza/daca-zf-a-imaginat-un-exercitiu-in-care-in-loc-de-1-8-mld-euro-am-fi-luat-10-mldeuro-bani-europeni-10257897

Dootz, R. (2000). Statistics assisted by SAS software, 165-170. Sibiu: Tipotrib Press.

Economist, T. (2012). The next crisis, Sponging boomers- The economic legacy left by the baby-boomers is leading to a battle between generations. The Economist Publishing House

European Commission. (2008). Demography Report.

European Economic and Social Committee. (2011, July 7). Press Release no 77/2011. http://populatiaromanieiincotro.unfpa.ro/demografic. $\quad$ (n.d.). $\quad$ Retrieved populatiaromanieiincotro.unfpa.ro.

EUROSTAT Statistical Books. (2012). Active ageing and solidarity between generations.

Hyman, D. N. (2007). Public Finance. (N. C. University, Ed.) The Dryden Press.

Lee, R. (2005). Quantifying our ignorance: stochastic forecast of population and public budgets. In L. Waite, Aging, Health, and public policy-demographic and economic perspectives (pp. 172-173), New York.

Mcmorrow, K., \& Roeger, W. (2010). The economic consequences of aging population, a comparison of the EU, US and Japan, 65- 68.

Paul, A. (2012). Economic dependency ratio has worsened.

Roubini. (2012). www.roubini.com. Retrieved may 10, 2012, from www.roubini.com: http://roubini.com

Ruggeri Joe, \& Zou, Y. (2010). The fiscal burden of rising dependency ratios, 192-195. http://dx.doi.org/10.1007\%2Fs11113-007-9027-8

Spataro, L. R. T. (2012). Optimal taxation, critical-level utilitarianism and economic growth, 12. http://dx.doi.org/10.1016\%2Fj.jpubeco.2012.05.001

Suzman, R. (2005). Research on Population Aging at NIA: Retrospect and Prospect. In L. Waite, Aging, health, and public policy, 239-241, New York.

Türk, J. W. (2011). "Dependency Ratio Calculator" Simulation tool for the interraction between demography, pensions, and the labor market. OECD Series, 13.

Vermeend, R. V. (2008). Taxes and the economy: a survey on the impact of taxes on growth, employment, investment, consumption and the environment, 54-55. Edgar Publisher.

Wise, D. (2005). Social security provisions and older workers. In L. Waite, Aging, Health, and public policydemographic and economic perspectives, 185-186. New York.

www.econtext.ro. (2012). Retrieved 2012, from www.econtext.ro.

www.investorwords.com/1409/dependency_ratio. (n.d.). Retrieved may 13, 2012, from www.investorwords.com: http://www.investorwords.com/1409/dependency_ratio

\section{Notes}

Note 1. The prognoses are done taking into consideration the current trend. Just as history has shown before, sociologists have done prognosis which had significant errors due to the significant change of this trend, and the long term prognoses (40-50 years) have a high uncertainty degree. 